\title{
Neoproterozoic stratigraphic comparison of the Lesser Himalaya (India) and Yangtze block (south China): Paleogeographic implications
}

\author{
Ganqing Jiang* Department of Earth Sciences, University of California, Riverside, California 92521, USA \\ Linda E. Sohl ] Department of Earth and Environmental Sciences and Lamont-Doherty Earth Observatory of \\ Nicholas Christie-Blick - Columbia University, Palisades, New York 10964-8000, USA
}

\begin{abstract}
Recent studies of terminal Neoproterozoic rocks (ca. 590-543 Ma) in the Lesser Himalaya of northwestern India and the Yangtze block (south China) reveal remarkably similar facies assemblages and carbonate platform architecture, with distinctive karstic unconformities at comparable stratigraphic levels. These similarities suggest that south China may have been located close to northwestern India during late Neoproterozoic time, an interpretation permitted by the available, yet sparse paleomagnetic data. Additional parallels in older rocks of both blocks-similar rift-related siliciclastic-volcanic successions overlying metamorphic basement, and comparable glaciogenic intervals of possibly Sturtian and Marinoan or Varanger age-suggest that this spatial relationship may have developed earlier in the Neoproterozoic. With the exception of basal Cambrian phosphorite and comparable small shelly fossils, stratigraphic contrasts between northern India and south China and increasing biogeographic affinity between south China and northwestern Australia suggest that south China may have migrated toward northwestern Australia during the Cambrian.
\end{abstract}

Keywords: Neoproterozoic, Lesser Himalaya, India, south China, stratigraphic comparison, tectonic reconstruction.

\section{INTRODUCTION}

The hypothesized Proterozoic supercontinent of Rodinia has attracted considerable interest recently (e.g., Bartley and Kah, 2001; Powell and Meert, 2001). One point of debate concerns the position of south China within Rodinia. Paleomagnetic constraints for south China from 1100 to $500 \mathrm{Ma}$ are few, and available data permit several possible reconstructions (Evans et al., 2000). In one reconstruction, Li et al. (1995) suggested that south China was between the eastern side of the Australian craton and the western side of Laurentia. This interpretation was based in part upon the presence of 1.9-1.4 Ga crust in both Cathaysia (southeastern China; Fig. 1C) and the Priest River Complex (southwestern Canada) that could account for detrital zircons of appropriate age in the lower Belt Supergroup of Montana and adjacent Canada. Additional support for this hypothesis includes (1) the similarity in age and chemistry of mafic dikes and sills in southern Australia and south China (Li et al., 1999, 2003), (2) the existence of an erosional surface above ca. 825 Ma rocks in both regions (Li et al., 1999), and (3) similar rifting history between south China and southeastern Australia from ca. 820-750 Ma (Ling et al., 2003; Wang and $\mathrm{Li}, 2003$ ).

However, this reconstruction presents several difficulties: (1) other zircon provenance

\footnotetext{
*E-mail: ganqing@mail.ucr.edu.
}

evidence places Australia directly against Laurentia, although details of the configuration and timing of breakup remain elusive (e.g., Wingate and Giddings, 2000; Karlstrom et al., 2001); (2) the synrift to early passive-margin succession of south China (ca. 820-750 Ma) resembles coeval strata of the eastern Australian craton and western Laurentia only grossly (Drexel et al., 1993; Narbonne and Aitken, 1995; Wang and Li, 2003), and the orientation of sedimentary basins was not taken into account; (3) synrift magmatism from ca. 860$730 \mathrm{Ma}$ in Australia and south China is not unique (e.g., Singh et al., 2002); (4) early Neoproterozoic (ca. 950-850 Ma) collisionrelated volcanic rocks in south China (Ling et al., 2003) have no correlatives in southeastern Australia; and (5) the similarities in Cambrian faunal provinces between south China and northwestern Australia (e.g., Burrett et al., 1990) require south China to have migrated a great distance during late Neoproterozoic time. In light of these difficulties, we explore an alternative arrangement.

\section{NEOPROTEROZOIC STRATIGRAPHY OF INDIA AND SOUTH CHINA}

Neoproterozoic rifted margins developed along the northern edge of India (Fig. 1A; Kumar, 1985) and along the southeastern and western sides of the Yangtze block (Fig. 1C; Li et al., 1999). In both areas, the timing of the rift to postrift transition is tentatively in- terpreted to correspond with a level within the glaciogenic interval (Fig. 2). A passivemargin setting is inferred with confidence for postglacial carbonate rocks on the basis of platform scale, comparatively simple physical stratigraphic and facies architecture, and the thickness of successions, with no evidence for either syndepositional tectonism or igneous activity. Figure 2 summarizes pertinent lithostratigraphy and lateral facies variations.

\section{Preglacial Successions (Early Neoproterozoic)}

In the Lesser Himalaya, the preglacial succession consists of locally tuffaceous siliciclastic rocks and associated minor mafic volcanic rocks, possibly rift-related, unconformably overlying Mesoproterozoic metamorphic rocks (Kumar, 1985; interval A1 in Fig. 2A). Facies become finer overall toward the northwest, from nonmarine sandstone and conglomerate (Nagthat Formation) at the Nainital syncline to nearshore siltstone and sandstone (Chandpur and Nagthat Formations; Jaunsar Group) in the region between the Garhwal and Nigalidhar synclines, to shale, siltstone, and sandstone (Simla Group) at Simla (Fig. 1B). An erosional unconformity is present at or near the Chandpur-Nagthat contact. The age of the rocks is constrained indirectly by U-Pb dates of $771 \pm 2$ and $751 \pm$ 3 Ma for volcanic rocks (Malani igneous suite) west of the study area, in Rajasthan (Torsvik et al., 2001).

In south China, correlative strata (interval B1 in Fig. 2B) unconformably overlie $819 \pm$ $7 \mathrm{Ma}$ (U-Pb) granites (Ma et al., 1984) in the Yangtze Gorge area and Mesoproterozoic $(\geq 1000 \mathrm{Ma})$ metamorphic rocks assigned to the Lengjiaxi and Sibao Groups. Nonmarine sandstone in the Liantuo Formation is equivalent to the upper part of the Banxi Group (Wuqiangxi Formation), which is separated from shale and siltstone of the underlying Madiyi Formation by an erosional unconformity. At Huaihua (location 10 in Fig. 1D), the Banxi Group is composed mainly of basinal shale and siltstone with abundant turbidites. Associated rift-related mafic volcanic rocks and tuff (Li et al., 1999, and references therein) have been dated to $748 \pm 12 \mathrm{Ma}(\mathrm{U}-\mathrm{Pb} ; \mathrm{Ma}$ et al., 1984). 


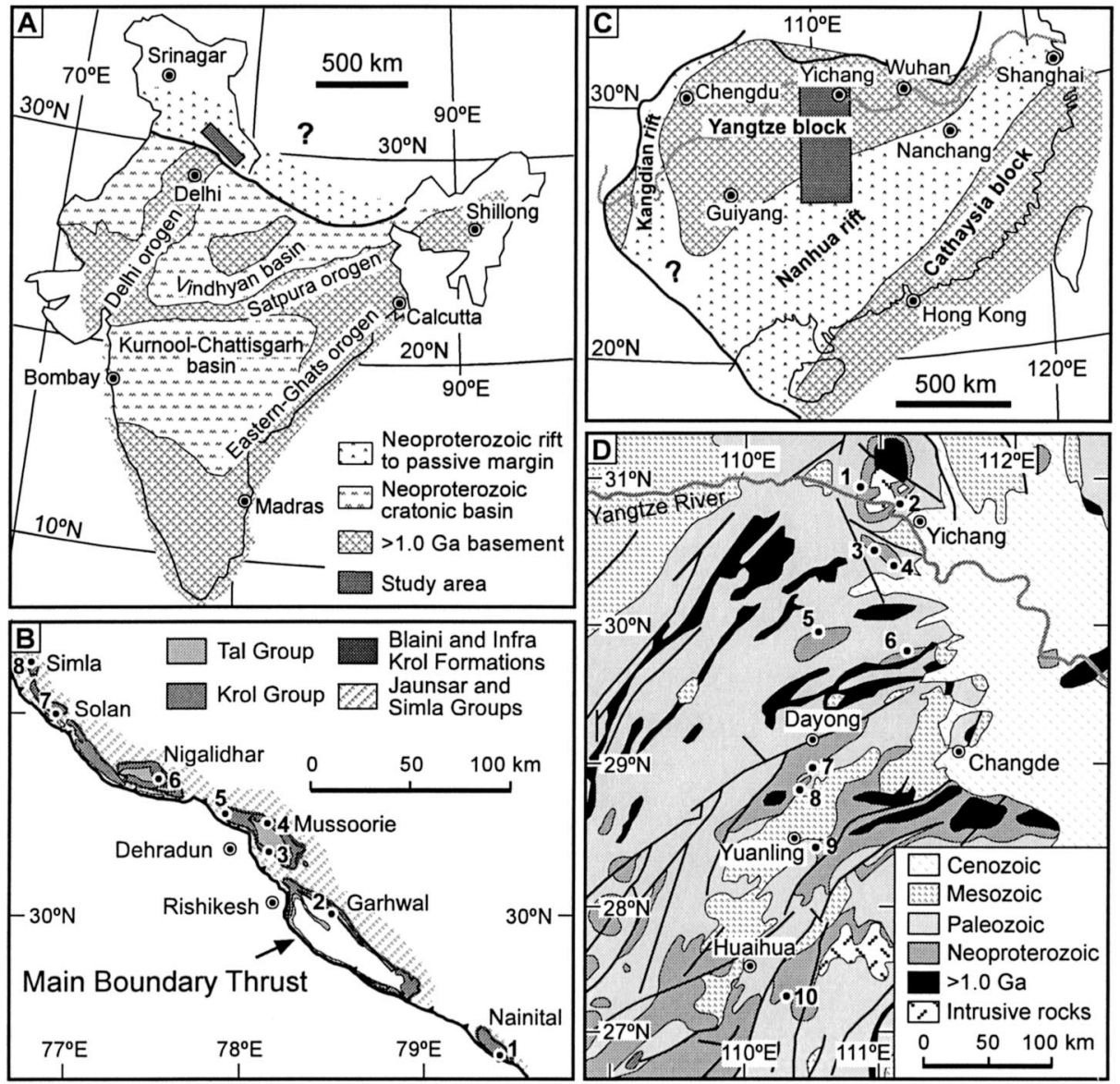

Figure 1. A: Neoproterozoic tectonic framework for India, emphasizing sedimentary basins ca. $800 \mathrm{Ma}$ (modified from Kumar, 1985). Southern limit of passive margin is approximated as Main Boundary thrust, and is not palinspastically reconstructed. B: Neoproterozoic and Cambrian outcrop in Lesser Himalaya, India, and sections used to construct Figure 2A. C: Neoproterozoic tectonic framework for south China, emphasizing inferred continental rift systems ca. $800 \mathrm{Ma}$ (modified from Li et al., 1999). D: Geologic map of study area, and sections used to construct Figure 2B.

\section{Synglacial Successions (Sturtian and}

Marinoan Glacial Intervals)

The Jaunsar and Simla Groups in northwestern India are unconformably overlain by glaciogenic diamictite, siltstone, and sandstone of the Blaini Formation (interval A2 in Fig. 2A). The Blaini is divided into a lower interval composed of three to four units of massive diamictite separated by siltstone and mudstone; a middle interval of siltstone and sandstone with lenses of ferruginous shale; and an upper interval of diamictite with an erosional unconformity at its base.

In south China, glaciogenic rocks unconformably overlie the Liantuo Formation or Banxi Group and are subdivided in a similar way (interval B2 in Fig. 2B). A lower diamictite interval (Jiangkou and Chang'an Formations) consists of several thick units of massive diamictite separated by siltstone and sandstone. A middle siltstone, shale, and sandstone sequence (Xiangmen and Datangpo Formations, and Fulu Formation at Guangxi, 200 $\mathrm{km}$ south of location 10 in Fig. 1D) is locally manganese rich, ferruginous, or dolomitic. An upper diamictite (Nantuo Formation) overlies an erosional unconformity (Jiang et al., 1996). The age of these rocks is still debated. Some researchers suggest that both Chang'an and Nantuo are Sturtian (e.g., Wang and Li, 2003) and that the negative $\delta^{13} \mathrm{C}$ excursion in the upper Doushantuo Formation (N2 in Fig. 2B) represents the Marinoan or Varanger glacial interval. However, the $\delta^{13} \mathrm{C}$ excursion is not associated with evidence for base-level lowering in either India or China (N2 in Figs. 2A and 2B; Jiang et al., 2002), a mismatch inconsistent with the interpretation of widespread glaciation elsewhere at that level. Given their overall context, we interpret the two diamictite intervals in both regions as Sturtian and Marinoan or Varanger, respectively.

\section{Postglacial Successions (Terminal Neoproterozoic)}

In both areas, the upper diamictite is overlain by a cap carbonate no more than a few meters thick (N1 in Figs. 2A and 2B), which is overlain by a siliciclastic to carbonate succession assigned to the Infra Krol Formation and Krol Group in India (interval A3 in Fig. $2 \mathrm{~A})$ and to the Doushantuo and Dengying Formations in China (interval B3 in Fig. 2B). The lower part of the Krol Group (Krol A) and the middle to upper part of the Doushantuo Formation contain phosphorite-chert nodules with distinctive acanthomorph acritarchs and the cyanobacteria Salome hubeiensis, which is known only from these two successions (AC in Figs. 2A and 2B; Tiwari and Knoll, 1994; Shuhai Xiao, 2003, personal commun.). Similar Ediacaran impressions have been reported from the Krol D and E in India and from the upper part of the Dengying Formation in China, although this fossil evidence is as yet inconclusive. The Lower Cambrian is marked by stratigraphic condensation, additional phosphorite, and comparable small shelly fossils in the basal Tal Group of India and in the Shuijintuo and Niutitang Formations of China.

In each area, the carbonate platform exhibits remarkably similar facies and stratigraphic details, including an evolution from mixed siliciclastic-carbonate ramp in the lower part, to rimmed shelf with marginal stromatoliterich complex in the middle, to open shelf in the upper part. Moreover, each succession is divisible into seven intervals bounded by regional stratigraphic discontinuities, distinctive unconformities termed sequence boundaries appearing at the same stratigraphic level. Prominent unconformities in the middle part of the Krol and lower part of the Dengying (surfaces 4 and 5 in Figs. 2A and 2B) show similar karstic features, including depressions with mappable relief, and breccias and calcrete filling dikes and smaller cavities (Jiang et al., 2002).

\section{PALEOGEOGRAPHIC IMPLICATIONS}

These stratigraphic similarities suggest a close paleogeographic relationship between the Yangtze block and the Lesser Himalaya during latest Neoproterozoic time (Fig. 3). Whether south China and India formed a contiguous passive margin is uncertain. The southwestern side of the Yangtze block was strongly deformed and metamorphosed during the Cenozoic, and the possible basement connection is difficult to evaluate. Various Tethyan Gondwana blocks (Fig. 3) were interpreted by Husseini and Husseini (1990) to have been sutured to the Salt Range-Kashmir region of greater India by ca. $620 \mathrm{Ma}$. In that case, a direct link between northwestern India and south China would be improbable when the stratigraphy of the two regions is most similar. The corresponding number and stratigraphic level of sequence boundaries in both regions suggest a eustatic influence on stratigraphic development as well as paleogeographic affinity.

An earlier spatial relationship between 


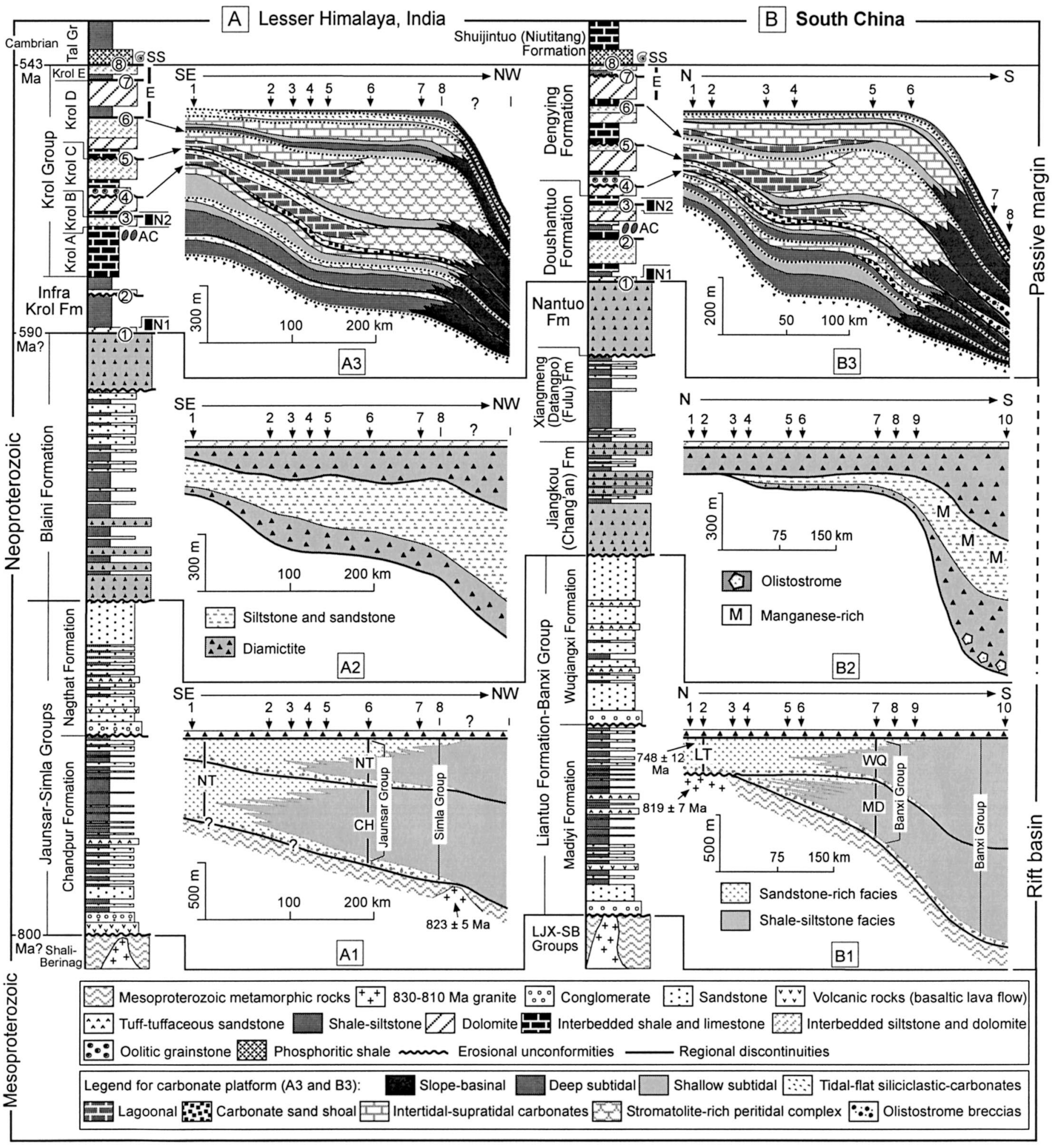

Figure 2. Generalized Neoproterozoic stratigraphy and regional stratigraphic cross sections for Lesser Himalaya, India (A) and south China (B). Numbered sections are located in Figure 1. A1: Jaunsar and Simla Groups. NT-Nagthat Formation; CH-Chandpur Formation. U-Pb age of $823 \pm 5 \mathrm{Ma}$ is from Singh et al. (2002). A2: Glaciogenic Blaini Formation. A3: Infra Krol Formation and Krol Group. AC-phosphoritechert nodules containing acanthomorph acritarchs and cyanobacteria Salome hubeiensis; E-interval of reported Ediacaran fossils; SSsmall shelly fossils; N1, N2-negative $\delta^{13} \mathrm{C}$ excursions; Gr-Group. Circled numbers 1-8 locate regional discontinuities and karstic and/or erosional unconformities. B1: Liantuo Formation (LT) and Banxi Group. WQ-Wuqiangxi Formation; MD-Madiyi Formation. LJX-SBLengjiaxi and Sibao Groups. U-Pb ages of $819 \pm 7 \mathrm{Ma}$ and $748 \pm 12 \mathrm{Ma}$ are from Ma et al. (1984). B2: Glaciogenic and associated units. B3: Doushantuo and Dengying Formations. Symbols and numbers as in A3. 


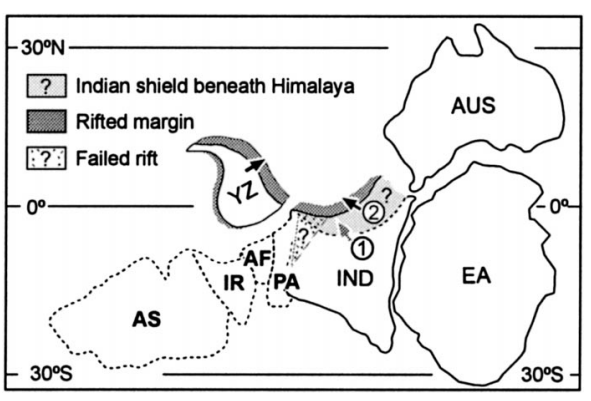

Figure 3. Proposed paleogeographic reconstruction for south China and northern India from terminal Neoproterozoic (ca. 590-543 $\mathrm{Ma}$ ) to Early Cambrian. Paleolatitude sources: south China (Lin and Fuller, 1990), IndiaAustralia-East Antarctica (Torsvik et al., 2001). Relationship between India and Tethyan Gondwana blocks is from Husseini and Husseini (1990). YZ-Yangtze block (south China); AUS-Australia; EA-East Antarctica; IND-India; PA-Pakistan; AF-Afghanistan; IR-eastern Iran; AS-Arabian shield. Arrows indicate direction of shelf-to-basin transition in south China and northern India. Northern Indian margin is shown in two ways: (1) based on modern geography; and (2) with palinspastic correction, and employing $\sim 30^{\circ}$ counterclockwise rotation of Lesser Himalaya against Indian shield (e.g., Schill et al., 2002). Failed rift in northwestern India is inferred from presence of Malani igneous suite (ca. 771-750 Ma; Torsvik et al., 2001) and lack of subsequent rift-related activity.

south China and northwestern India is also possible but more difficult to demonstrate. Comparable rift-related magmatic events of ca. 830-795 Ma and ca. 780-745 Ma have been documented in both regions (Deb et al., 2001; Singh et al., 2002; Li et al., 2003), although the early Neoproterozoic volcanic rocks of South China have also been associated with southeastern Australia (Li et al., 1999, 2003), which was the site of some volcanism at that time (Drexel et al., 1993). Paleomagnetic data suggest a polar location for India ca. $825 \mathrm{Ma}$ (Radhakrishna and Mathew, 1996), but no data for this interval are currently available for south China. Sparse paleomagnetic data from south China (Evans et al., 2000) and northwestern India (Torsvik et al., 2001) taken from rocks ca. $750 \mathrm{Ma}$ in age indicate that both blocks occupied midlatitude positions at that time, and a lack of longitudinal constraints permits the blocks to be in relatively close proximity.

Evidence that India had moved into a lowlatitude position adjacent to East Antarctica during the Early Cambrian amalgamation of East Gondwana is more persuasive (e.g., Torsvik et al., 2001). South China also occupied a low-latitude position at that time (Lin and Fuller, 1990). The stratigraphic development of northwestern India and south China diverged after the earliest Cambrian; in India, the siliciclastic Tal Group is unconformably overlain by Permian rocks, whereas a carbonate platform persisted in south China until the Silurian. South China may have begun to drift away from northwestern India and toward northwestern Australia in the Early Cambrian, a juxtaposition consistent with the close biogeographic affinity between south China and northwestern Australia in the early to middle Paleozoic (e.g., Burrett et al., 1990).

\section{ACKNOWLEDGMENTS}

Supported by National Science Foundation grants EAR-96-14070 and INT-00-89252 (to ChristieBlick), and ATM-99-07640 and EAR-00-87559 (to Christie-Blick and Sohl); a Geological Society of America Student Research Grant (to Jiang); the Department of Earth and Environmental Sciences of Columbia University; and a grant of the State Science and Technology Committee of China (to Wang Hongzhen). We thank D.M. Banerjee, Ziqiang Wang, Shihong Zhang, Huaichun Wu, and Guobiao $\mathrm{Li}$ for assistance over several field seasons, and journal reviewers J. Geissman, C.T. Klootwijk, and B.A. van der Pluijm for constructive advice. D.A.D. Evans, Z.X. Li, J.G. Meert, and an anonymous referee reviewed an earlier version. This is a contribution to International Geological Correlation Programme Project 440. Lamont-Doherty Earth Observatory contribution 6482.

\section{REFERENCES CITED}

Bartley, J.K., and Kah, L.C., eds., 2001, Rodinia and the Mesoproterozoic Earth-ocean system: Precambrian Research, v. 111, p. 1-281.

Burrett, C., Long, J., and Stait, B., 1990, Early-Middle Palaeozoic biogeography of Asian terranes derived from Gondwana, in McKerrow, W.S., and Scotese, C.R., eds., Palaeozoic palaeogeography and biogeography: Geological Society [London] Memoir 12, p. 163-174.

Deb, M., Thorpe, R.I., Krstic, D., Corfu, F., and Davis, D.W., 2001, Zircon U-Pb and galena $\mathrm{Pb}$ isotope evidence for an approximate $1.0 \mathrm{Ga}$ terrane constituting the western margin of the AravalliDelhi orogenic belt, northwestern India: Precambrian Research, v. 108, p. 195-213.

Drexel, J.F., Preiss, W.V., and Parker, A.J., eds., 1993, The geology of South Australia: The Precambrian: Geological Survey of South Australia Bulletin 54, v. 1, 242 p.

Evans, D.A.D., Li, Z.X., Kirschvink, J.L., and Wingate, M.T.D., 2000, A high-quality midNeoproterozoic paleomagnetic pole from South China, with implications for ice ages and the breakup configuration of Rodinia: Precambrian Research, v. 100, p. 313-334

Husseini, M.I., and Husseini, S.I., 1990, Origin of the Infracambrian salt basins of the Middle East, in Brooks, J., ed., Classic petroleum provinces: Geological Society [London] Special Publication 50, p. $279-292$.

Jiang, G., Wang, Z., and Zhang, L., 1996, Sequence stratigraphy of upper Proterozoic glacigenous rocks in southeastern margin of Yangtze platform: Journal of China University of Geosciences (English edition), v. 7, p. 38-45.

Jiang, G., Christie-Blick, N., Kaufman, A.J., Banerjee, D.M., and Rai, V., 2002, Sequence stratigraphy of the terminal Proterozoic Krol Group and Infra Krol Formation, Lesser Himalaya, India: Journal of Sedimentary Research, v. 72, p. 524-542.

Karlstrom, K.E., Ahall, K.I., Harlan, S.S., Williams, M.L., McLelland, J., and Geissman, J.W., 2001, Long-lived (1.8-1.0 Ga) convergent orogen in southern Laurentia, its extensions to Australia and Baltica, and implications for refining Rodinia: Precambrian Research, v. 111, p. 5-30.

Kumar, R., 1985, Fundamentals of historical geology and stratigraphic of India: New Delhi, Wiley Eastern Limited, p. 81-803.

Li, Z.X., Zhang, L., and Powell, C.M., 1995, South China in Rodinia: Part of the missing link between Australia-East Antarctica and Laurentia? Geology, v. 23, p. 407-410.

Li, Z.X., Li, X.H., Kinny, P.D., and Wang, J., 1999 The breakup of Rodinia: Did it start with a mantle plume beneath South China?: Earth and Planetary Science Letters, v. 173, p. 171-181.

Li, Z.X., Li, X.H., Kinny, P.D., Wang, J., Zhang, S., and Zhou, H., 2003, Geochronology of Neoproterozoic syn-rift magmatism in the Yangtze craton, South China, and correlations with other continents: Evidences for a mantle superplume that broke up Rodinia: Precambrian Research, v. 122 , p. $85-109$.

Lin, J.L., and Fuller, M., 1990, Palaeomagnetism, North China and South China collision, and the Tan-Lu fault: Royal Society of London Philosophical Transactions, ser. A, v. 331 , p. $589-598$.

Ling, W., Gao, S., Zhang, B., Li, H., Liu, Y., and Cheng, J., 2003, Neoproterozoic tectonic evolution of the northwestern Yangtze craton, South China: Implications for amalgamation and breakup of the Rodinia supercontinent: Precambrian Research, v. 122, p. 111-140.

Ma, G., Lee, H., and Zhang, Z., 1984, An investigation of the age limits of the Sinian System in south China: Chinese Academia of Geological Sciences, Bulletin of Yichang Institute of Geology and Mineral Resources, v. 8, p. 1-29 (in Chinese).

Narbonne, G.M., and Aitken, J.D., 1995, Neoproterozoic of the Mackenzie Mountains, northwestern Canada: Precambrian Research, v. 73, p. $101-121$

Powell, C.M., and Meert, J.G., eds., 2001, Assembly and breakup of Rodinia: Precambrian Research, v. $110,383 \mathrm{p}$

Radhakrishna, T., and Mathew, J., 1996, Late Precambrian (850-800 Ma) palaeomagnetic pole for the south Indian shield from the Harohalli alkaline dykes: Geotectonic implications for Gondwana reconstructions: Precambrian Research, v. 80, p. 77-87.

Schill, E., Crouzet, C., Gautam, P., Singh, V.K., and Appel, E., 2002, Where did rotational shortening occur in the Himalayas? - Inferences from paleomagnetic remagnetisations: Earth and Planetary Science Letters, v. 203, p. 45-57.

Singh, S., Barley, M.E., Brown, S.J., Jain, A.K., and Manickavasagam, R.M., 2002, SHRIMP U-Pb in zircon geochronology of the Chor granitoid: Evidence for Neoproterozoic magmatism in the Lesser Himalayan granite belt of northwest India: Precambrian Research, v. 118, p. 285-292.

Tiwari, M., and Knoll, A.H., 1994, Large acanthomorphic acritarchs from the Infrakrol Formation of the Lesser Himalaya and their stratigraphic significance: Journal of Himalayan Geology, v. 5 , p. $193-201$.

Torsvik, T.H., Carter, L.M., Ashwal, L.D., Bhushan, S.K., Pandit, M.K., and Jamtveit, B., 2001, Rodinia refined or obscured: Palaeomagnetism of the Malani igneous suite (northwest India): Precambrian Research, v. 108, p. 319-333.

Wang, J., and Li, Z.X., 2003, History of Neoproterozoic rift basins in South China: Implications for Rodinia break-up: Precambrian Research, v. 122, p. 141-158.

Wingate, M.T.D., and Giddings, J.W., 2000, Age and palaeomagnetism of the Mundine Well dyke swarm, Western Australia: Implications for an Australia-Laurentia connection at 755 Ma: Precambrian Research, v. 100, p. 335-357.

Manuscript received 1 May 2003

Revised manuscript received 1 July 2003

Manuscript accepted 8 July 2003

Printed in USA 